\title{
Analisis Pembelajaran Berbasis Problem Based Learning (PBL) Terhadap Kemampuan Kritis Mahasiswa
}

\author{
Susdarwati \\ Program Studi Pendidikan IPA, STKIP Modern Ngawi \\ Email: susdarwati88sains@gmail.com
}

\begin{abstract}
Abstrak
Program Studi Pendidikan IPA STKIP Modern Ngawi mewajibkan tenaga pengajar untuk menerapkan model pembelajaran yang bisa meningkatkan kemampuan berpikir kritis mahasiswa salah satunya adalah Problem Based Learning (PBL). Tujuan penelitian ini adalah untuk 1) mendeskripsikan perencanaan pembelajaran berbasis Problem Based Learning (PBL) terhadap kemampuan kritis mahasiswa; 2) mendeskripsikan proses pembelajaran berbasis Problem Based Learning (PBL) terhadap kemampuan kritis mahasiswa. Jenis penelitian adalah penelitian kualitatif. Sampel yang digunakan adalah kelas A02 Semester 4 STKIP Modern Ngawi yang berjumlah 18 mahasiswa dengan rincian laki-laki berjumlah 5 dan perempuan berjumlah 13 mahasiswa. Teknik pengumpulan data dilakukan dengan cara analisis data kualitatif yang mengikuti konsep Miles dan Huberman yaitu dengan alur reduksi data, penyajian data, dan penarikan kesimpulan. Hasil penelitian menunjukkan bahwa: 1) Perencanaan pembelajaran dianalisis dari penyusunan RPP sudah baik sekali, hal ini ditunjukkan dalam RPP sudah terlengkapi dengan PBL antara lain tujuan pembelajaran, mengembangkan kegiatan pembelajaran, penjabaran jenis penilaian, menentukan alokasi waktu, dan menentukan sumber belajar; dan 2) Proses pembelajaran sudah baik, hal ini ditunjukkan dengan a) sintaks pembelajaran Problem Based Learning (PBL) terlaksana dengan baik, b) kemampuan berpikir kritis mahasiswa meliputi elementary clarification, basic support, dan inference dalam kategori cukup.
\end{abstract}

Kata Kunci: problem based learning, kemampuan kritis, mahasiswa

\section{PENDAHULUAN}

Tujuan pendidikan nasional dirumuskan dalam Undang-undang Nomor 20 tahun 2003 tentang sistem pendidikan nasional, bahwa pendidikan nasional bertujuan untuk berkembangnya potensi peserta didik agar menjadi manusia yang beriman dan bertaqwa pada Tuhan Yang Maha Esa, berahlak mulia, sehat, berilmu, cakap, kreatif, mandiri, dan menjadi warga negara yang demokratis dan bertanggung jawab. Pendidikan memegang peranan yang sangat penting dalam menciptakan manusia yang berkualitas. Pendidikan juga dipandang sebagai sarana untuk melahirkan insan-insan yang cerdas, kreatif, terampil, bertanggung jawab, produktif dan berbudi luhur.

Program Studi Pendidikan IPA STKIP Modern Ngawi mewajibkan tenaga pendidik untuk mengembangkan pembelajaran melalui strategi pembelajaran yang berbasis masalah. Salah satu tujuannya adalah agar mahasiswa memiliki kemampuan untuk berpikir kritis. Supaya pembelajaran di dalam kelas menarik dan penuh makna, tenaga pendidik perlu mendesain rencana pembelajaran yang memungkinkan peserta didik berinteraksi aktif dalam pembelajaran. Begitu pula dalam pembelajaran Fisika Dasar II yang selama ini dianggap sebagai pembelajaran yang sulit dan membosankan. Motivasi serta minat belajar mahasiswa kurang. Padahal pembelajaran Fisika Dasar II mempunyai peranan penting dalam mengembangkan keterampilan dan berpikir logis, kritis, sistematis, dan kreatif. Untuk itu kreativitas tenaga pendidik dalam proses pembelajaran Fisika Dasar II agar dapat menarik dan tidak membosankan sangat diperlukan. Namun, banyak mahasiswa menganggap Fisika 
Dasar II sebagai materi yang sulit untuk dipelajari. Selain itu, banyak mahasiswa mempunyai sikap pesimis serta motivasi yang kurang dalam belajar Fisika Dasar II. Indikator yang digunakan sebagai acuan untuk menyatakan keberhasilan dalam pembelajaran adalah daya serap mahasiswa terhadap suatu materi yang diberikan.

Hal di atas hendaknya menjadi latar belakang tercipta pengembangan dalam pembelajaran Fisika Dasar II. Salah satu solusi yang mungkin akan membantu yakni dengan melakukan analisis terhadap sebuah metode pembelajaran yang digunakan. Diharapkan dengan adanya analisis tersebut dapat membantu pencapaian tujuan dari sebuah pembelajaran, serta tidak menutup kemungkinan analisis tersebut dapat digunakan sebagai dasar untuk melakukan pengembangan dari sebuah strategi pembelajaran. Salah satunya adalah Problem Based Learning (PBL).

Problem Based Learning (PBL) wajib diterapkan dalam pembelajaran Fisika Dasar II agar terjadi pembelajaran yang bermakna. Mahasiswa yang belajar memecahkan suatu masalah akan menerapkan pengetahuan yang dimilikinya atau berusaha mengetahui pengetahuan yang diperlukan. Belajar dapat semakin bermakna dan dapat diperluas ketika mahasiswa berhadapan dengan situasi di mana konsep ditemukan ketika melakukan percobaan. Pembelajaran berdasarkan masalah dapat diterapkan untuk merangsang berpikir tingkat tinggi dalam situasi berorientasi masalah, termasuk di dalamnya belajar bagaimana belajar (Ibrahim, 2008: 5). Dalam situasi Problem Based Learning (PBL), peserta didik mengintegrasikan pengetahuan dan keterampilan secara simultan dan mengaplikasikannya dalam konteks yang relevan. Artinya, bahwa yang mereka lakukan sesuai dengan keadaan nyata sehingga masalahmasalah dalam aplikasi suatu konsep atau teori mereka akan temukan sekaligus selama pembelajaran berlangsung (Sardiman, 2011: 38).

Pelaksanaan pembelajaran berbasis masalah akan lebih baik jika dapat meningkatkan kemampuan berpikir kritis. Kemampuan berpikir membantu peserta didik menyelesaikan permasalahan kehidupan sehari-hari. Khususnya dengan berpikir kritis, peserta didik dapat memutuskan langkah apa yang tepat untuk menyelesaikan permasalahanya dengan memikirkan dampak yang akan dihasilkan dari langkah tersebut. Jika dampak yang dihasilkan kurang baik, maka peserta didik secara kritis mencari tahu apa penyebabnya dan alternatif penyelesaian yang lain.

Selain itu, berpikir kritis dapat membantu seseorang memahami bagaimana ia memandang dirinya sendiri, bagaimana ia memandang dunia, dan bagaimana ia berhubungan dengan orang lain, membantu memahami perilaku diri sendiri, dan menilai diri sendiri (Lambertus, 2009). Kemampuan berpikir kritis dapat ditingkatkaan melalui kegiatan pembelajaran yang mendorong peserta didik untuk aktif dalam mencari informasi dari berbagai sumber, menjelaskan informasi dan situasi yang dihadapi, mencari solusi yang tepat ketika mendapatkan masalah, serta menilai dan bertanggung jawab atas segala tindakan yang dilakukan. PBL merupakan pembelajaran yang dapat memfasilitasi kegiatan dalam upaya meningkatkan kemampuan berpikir kritis matematis yang menekankan pada suatu masalah. Pembelajaran berbasis masalah memberi pengertian bahwa dalam pembelajaran peserta didik dihadapkan pada suatu masalah, yang kemudian diharapkan melalui pemecahan masalah peserta didik belajar keterampilanketerampilan berpikir yang lebih mendasar (Husnidar, Ihsan, dan Rizal, 2014).

Berdasarkan uraian sebelumnya, peneliti tertarik untuk mengadakan penelitian berupa analisis pembelajaran berbasis Problem Based Learning (PBL) karena untuk mengetahui mutu 
perencanaan dan proses pembelajaran yang sudah dilakukan.

\section{METODE}

Jenis penelitian ini termasuk penelitian kualitatif. Menurut Nasution (Sugiyono, 2008: 205) penelitian diskriptif kualitatif pada hakikatnya adalah mengamati orang dalam lingkungan hidupnya, berinteraksi dengan mereka, berusaha memahami bahasa dan tafsiran mereka tentang dunia sekitar.

Dalam penelitian ini yang akan dianalisis yakni perencanaan dan proses pembelajaran berbasis PBL yang sudah dilakukan. Dengan digunakannya penelitian kualitatif, maka data yang didapatkan akan lebih lengkap, lebih mendalam dan bermakna sehingga tujuan dari penelitian ini dapat tercapai.

Teknik pengambilan subjek penelitian ini adalah Purposive sampling. Purposive sampling adalah teknik pengambilan sumber data dengan pertimbangan maksud tertentu sesuai dengan tujuan penelitian ini dilaksanakan. Sumber informan penelitian adalah orang yang dianggap dapat memberikan informasi yang dibutuhkan peneliti yaitu dosen yang mengampu mata kuliah Fisika Dasar II.

Data utama penelitian ini berupa informasi tentang proses pembelajaran yang meliputi perencanaan dan pelaksanaan pada proses pembelajaran. Informasi tentang perencanaan proses pembelajaran diperoleh melalui dokumentasi dokumen-dokumen pendukung dan wawancara dosen X Pengampu mata kuliah Fisika Dasar II. Informasi tentang pelaksanaan kegiatan pembelajaran dan kendala pembelajaran diperoleh melalui observasi pelaksanaan kegiatan pembelajaran dan wawancara.

\section{HASIL DAN PEMBAHASAN}

Tujuan penelitian ini yaitu untuk mendiskripsikan perencanaan dan proses pembelajaran berbasis Problem Based Learning (PBL).

A. Hasil Penelitian

1.Analisis Data Perencanaan Pembelajaran Berbasis Problem Based Learning (PBL)

Data perencanaan pembelajaran berbasis Problem Based Learning (PBL) meliputi data tentang proses penyusunan RPP mata kuliah Fisika Dasar II. Data hasil dokumentasi dokumen-dokumen pendukung dan data dalam bentuk transkrip wawancara subjek AD dengan subjek FH.

Data proses penyusunan RPP dalam penelitian ini berupa dokumentasi dokumen pendukung yaitu RPP Mata Kuliah Fisika Dasar II dijelaskan langkah-langkah penyusunan meliputi: a) menentukan tujuan, b) mengembangkan kegiatan pembelajaran, c) penjabaran jenis penilaian, d) menentukan alokasi waktu, e) menentukan sumber belajar. Hasil wawancara pada kategori tersebut masingmasing akan dijelaskan sebagai berikut.

a.Menetukan Tujuan Pembelajaran

Kategori ini berisi tentang ucapan dosen dalam merumuskan tujuan pembelajaran pada RPP. Data perumusan tujuan pembelajaran hasil wawancara dengan subjek AD dan subjek FH masing-masing akan dijelaskan sebagai berikut.

1) Data Perumusan Tujuan Pembelajaran oleh Subjek AD

Pada penyusunan RPP dosen dapat mengembangkan dari indicator yang terdapat pada silabus. Dari indikator tersebut digunakan dosen untuk merumuskan tujuan pembelajaran.

2) Data Perumusan Tujuan Pembelajaran Oleh Subjek FH

Pada penyususnan RPP dosen pengampu mata kuliah Fisika Dasar II mengacu pada silabus yang sudah sesuai dengan asosiasi Perkumpulan Pendidik IPA Indonesia (PPII). Indikator dalam silabus digunakan untuk acuan merumuskan tujuan pemebelajaran.

Menurut pembahasan dalam menetukan tujuan pembelajaran maka dosen 
mengembangkan dari indikator yang ada dan kemudian indikator tesebut dijadikan acuan untuk merumuskan tujuan pembelajaran dan paling tidak mengandung dua aspek peserta dan aspek kemampuan.

Berdasarkan analisis data tentang perumusan tujuan pembelajaran dapat disimpulkan bahwa penyusunan RPP kategori perumusan tujuan pembelajaran adalah sebagai berikut.

Tabel 1. Hasil Analisis Data Perumusan Tujuan

Pembelajaran

\begin{tabular}{|c|c|}
\hline \multicolumn{2}{|c|}{ Perumusan Tujuan Pembelajaran } \\
\hline Subjek AD & Subjek FH \\
\hline $\begin{array}{lr}\text { Penyusunan } & \text { RPP } \\
\text { mengacu pada } & \text { silabus } \\
\text { yang dimiliki kemudian } \\
\text { dikembangkan sesuai } \\
\text { dengan karakteristik } \\
\text { mahasiswa r prodi } \\
\text { Pendidikan IPA STKIP } \\
\text { Modern } \\
\text { Merumuskan indikator } \\
\text { dari materi dalam } \\
\text { silabus dan disesuaikan } \\
\text { dengan buku ajar yang } \\
\text { digunakan dalam proses } \\
\text { pembelajaran. Kemudian } \\
\text { tujuan pembelajaran } \\
\text { mengacu pada indikator. }\end{array}$ & 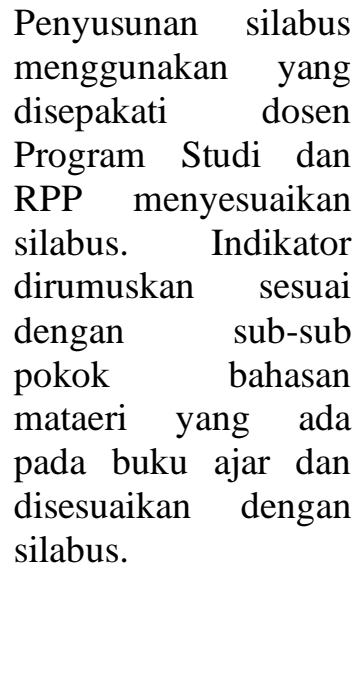 \\
\hline $\begin{array}{l}\text { Hasil triangulasi sumber } \\
\text { tujuan pembelajaran: } \\
\text { Penyusunan tujuan pemb } \\
\text { indikator. Untuk Merun } \\
\text { dari materi dalam sil } \\
\text { dengan buku ajar yang d } \\
\text { pembelajaran. Penyusuna } \\
\text { silabus yang dimiliki ke } \\
\text { sesuai dengan karakteri } \\
\text { Pendidikan IPA STKIP N }\end{array}$ & $\begin{array}{l}\text { dari data perumusan } \\
\text { lajaran mengacu pada } \\
\text { uskan indikator yaitu } \\
\text { bus dan disesuaikan } \\
\text { gunakan dalam proses } \\
\text { h RPP mengacu pada } \\
\text { nudian dikembangkan } \\
\text { tik mahasiswa prodi } \\
\text { odern Ngawi. }\end{array}$ \\
\hline
\end{tabular}

b. Mengembangkan Kegiatan Pembelajaran

Kategori ini berisi tentang ucapan dosen dalam merencanakan kegiatan pembelajaran pada RPP. Data mengembangkan kegiatan pembelajaran hasil wawancara dengan subjek $\mathrm{AD}$ dan $\mathrm{FH}$ masing-masing akan dijelaskan sebagai berikut.
1) Data Mengembangkan
Kegiatan
Pembelajaran oleh subjek AD

$\mathrm{AD}$ menjelaskan dalam mengembangkan kegiatan pembelajaran disesuaikan dengan tujuan pembelajaran yang akan dicapai. Dimulai dari kegiatan awal, inti, dan penutup. Kegiatan inti menjadi rincian dari kegiatan pembelajaran berbasis PBL, yakni: mengamati, menanya, mengumpulkan informasi, mengasosiasikan dan mengkomunikasikan, yang masing-masing urutannya disesuaikan dengan tujuan pembelajaran yang telah ditentukan.

Dosen sudah mengintegrasikan langkahlangkah pembelajaran berbasis PBL dalam kegiatan inti pada penyusunan RPP.
2) Data Mengembangkan Kegiatan
Pembelajaran oleh Subjek FH

FH dalam merencanakan kegiatan pembelajaran dimulai dari merencanakan kegiatan awal, kegiatan inti, dan kegiatan penutup sebagaimana yang sudah ada di silabus. Berdasarkan analisis data tentang pengembangan kegiatan pembelajaran dapat disimpulkan sebagai berikut.

Tabel 2. Hasil analisis data pengembangan kegiatan pembelajaran hasil triangulasi sumber

\begin{tabular}{|c|c|}
\hline \multicolumn{2}{|c|}{ Pengembangan Kegiatan Pembelajaran } \\
\hline Subjek AD & Subjek FH \\
\hline $\begin{array}{l}\text { Dalam RPP dosen tidak } \\
\text { mengembangkan kegiatan } \\
\text { pembelajaran secara } \\
\text { langsung maka dosen } \\
\text { menggunakan tahapan } \\
\text { kegiatan pembelajaran } \\
\text { yang sudah ada dalam } \\
\text { silabus. Langkah-langkah } \\
\text { pembe-lajaran berbasis } \\
\text { PBL diintegrasikan pada } \\
\text { kegiatan inti. }\end{array}$ & $\begin{array}{l}\text { Dalam RPP dosen } \\
\text { tidak } \\
\text { mengembangkan } \\
\text { kegiatan } \\
\text { pembelajaran. } \\
\text { Karena di dalam } \\
\text { silabus sudah } \\
\text { terdapat kegiatan } \\
\text { pembelajaran. Jika } \\
\text { ada pengembangan } \\
\text { tidak ditulis rinci } \\
\text { pada RPP, namun } \\
\text { dilaksanakan ketika } \\
\text { pembelajaran } \\
\text { berlangsung. }\end{array}$ \\
\hline $\begin{array}{l}\text { Hasil Triangulasi } \\
\text { Pengembangan Kegiatan } \\
\text { RPP guru tidak meng } \\
\text { pembelajaran sendiri. K } \\
\text { berbasis PBL tersebut } \\
\text { kegiatan pembelajaran y }\end{array}$ & $\begin{array}{l}\text { Sumber Analisis } \\
\text { Pembelajaran: Dalam } \\
\text { embangkan kegiatan } \\
\text { egiatan pembelajaran } \\
\text { disesuaikan dengan } \\
\text { ang ada pada silabus }\end{array}$ \\
\hline
\end{tabular}

c. Penjabaran Jenis Penilaian

Kategori ini berisi tentang ucapan dosen dalam menetukan penilaian dalam RPP. Dari 
hasil analisi dokumen penilaian pembelajaran sudah tercantum dalam silabus. Sedangkan data penetuan penilaian pembelajaran hasil wawancara dengan subjek $\mathrm{AD}$ dan $\mathrm{FH}$ masingmasing akan dijeaskan sebagai berikut.

1) Data Penentuan Penilaian Oleh Subjek AD

Dalam penyusunan RPP AD tidak menentukan penilaian sendiri. AD menggunakan acuan dari silabus yang sudah ada.

\section{2) Data Penentuan Penialaian Oleh Subjek FH}

Penetuan penilaian yang dilakukan dosen mengacu pada silabus, berarti dosen tidak menentukan sendiri penilaian yang digunakan.

Berdasarkan analisis data tentang penentuan penilaian dapat disimpulkan bahwa proses penyusunan RPP kategori penetuan penilaian adalah sebagai berikut.

Tabel 3. Hasil Analisis Data Penetuan Penilaian Dan Hasil Triangulasi Sumber

\begin{tabular}{|c|c|}
\hline \multicolumn{2}{|c|}{ Pentuan Penilaian } \\
\hline Subjek AD & Subjek FH \\
\hline $\begin{array}{lr}\begin{array}{l}\text { Dosen } \\
\text { menentukan }\end{array} & \text { tidak } \\
\text { jenis } & \text { sendiri } \\
\text { melainkan } & \\
\text { menggiaian } \\
\text { penialaian } & \\
\text { dicantumkan } & \text { yang } \\
\text { silabus. } & \text { didalam } \\
\text { penilaian ada } & \text { empat } \\
\text { yaitu, harian, } & \text { tugas, } \\
\text { UTS, dan UAS. } & \end{array}$ & $\begin{array}{lr}\text { Dosen mengacu pada } \\
\text { penilaian yang ada pada } \\
\text { silabus yang ada dalam } \\
\text { program studi. } \\
\text { dalam Dosen } \\
\text { mencantumkan rubrik } \\
\text { namun hal tersebut tidak } \\
\text { digunakan } & \text { ketika } \\
\text { pembelajaran } & \\
\text { berlangsung. } & \end{array}$ \\
\hline $\begin{array}{l}\text { Hasil Triangulasi sumb } \\
\text { Dalam RPP dosen } \\
\text { penialaian pembelajara }\end{array}$ & $\begin{array}{l}\text { ata penentuan penilaian: } \\
\mathrm{k} \text { menentukan sendiri }\end{array}$ \\
\hline
\end{tabular}

\section{d. Menentukan Alokasi Waktu}

Data dari hasil wawancara dengan subjek AD dan FH sama-sama mengguanakan acuan yang terdapat dalam silabus. Sesuai dengan dokumentasi dan wawancara sebagai berikut.

1) Data penetuan Alokasi waktu oleh subjek $\mathrm{AD}$

Penentuan alokasi waktu pada setiap Kemampuan Akhir Yang Direncanakan didasarkan pada jumlah minggu efektif dan alokasi waktu mata pelajaran per minggu dengan mempertimbangkan jumlah Kemampuan Akhir Yang Direncanakan, keluasan, kedalaman, tingkat kesulitan, dan tingkat kepentingan Kemampuan Akhir Yang Direncanakan.

2) Data Penentuan Alokasi waktu oleh subjek $\mathrm{FH}$

Alokasi waktu yang dicantumkan dalam silabus merupakan perkiraan waktu rerata untuk menguasai $\mathrm{KD}$ yang dibutuhkan oleh peserta didik yang beragam.

Berdasarkan analisis data tentang alokasi waktu dapat disimpulkan bahwa proses penyusunan RPP kategori penetuan penilaian adalah sebagai berikut.

Tabel 4. Hasil analisi data penentuan alokasi waktu dan hasil triangulasi sumber

\begin{tabular}{|c|c|}
\hline \multicolumn{2}{|c|}{ Penetuan Alokasi Waktu } \\
\hline Subjek AD & Subjek FH \\
\hline 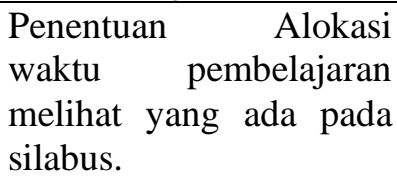 & $\begin{array}{l}\text { Gunakan alokasi } \\
\text { yang sudah ada pada } \\
\text { silabus. }\end{array}$ \\
\hline $\begin{array}{l}\text { Hasil Triangulasi sumber } \\
\text { waktu: } \\
\text { Alokasi waktu m } \\
\text { Kemampuan Akhir Yang }\end{array}$ & $\begin{array}{l}\text { data penentuan alokasi } \\
\text { nyesuaikan jumlah } \\
\text { Direncanakan. }\end{array}$ \\
\hline
\end{tabular}

e. Menentukan Sumber Belajar

Data penentuan sumber belajar hasil wawancara dengan subjek AD dan FH masingmasing akan dijelaskansebagai berikut.

1) Data penentuan sumber belajar oleh subjek $\mathrm{AD}$

Dalam silabus sudah terdapat sumber belajar yang digunakan. Mahasiswa menguanakan semua sumber belajar dibolehkan. 2. Data penentuan sumber belajar oleh subjek $\mathrm{FH}$

2) Data penentuan sumber belajar oleh subjek $\mathrm{FH}$

Tidak berbeda dengan subjek AD, subjek FH juga tidak menggunakan semua sumber belajar yang tercantum didalam silabus. Berdasarkan analisis data tentang penentuan sumber belajar dapat disimpulkan bahwa penyusunan RPP 
kategori penentuan sumber belajar sebagai berikut.

Tabel 5. Hasil analisis data penentuan sumber belajar dan hasil triangulasi sumber

\begin{tabular}{|c|c|}
\hline \multicolumn{2}{|c|}{ Penentuan Sumber Belajar } \\
\hline Subjek AD & Subjek FH \\
\hline $\begin{array}{l}\text { Sumber belajar yang } \\
\text { terdapat didalam silabus } \\
\text { digunakan. } \\
\text { menggunakan buku ajar } \\
\text { Fisika Dasar II sebagai } \\
\text { sumber belajar. }\end{array}$ & $\begin{array}{l}\text { Dosen } \\
\text { menggunakan buku } \\
\text { ajar Fisika Dasar II } \\
\text { dan internet. }\end{array}$ \\
\hline $\begin{array}{l}\text { Hasil triangulasi Sumber dat } \\
\text { Sumber belajar yang di dal } \\
\text { yaitu buku ajar Fisika D } \\
\text { sesuai, dan internet. }\end{array}$ & $\begin{array}{l}\text { Sumber belajar: } \\
\text { m silabus yang }\end{array}$ \\
\hline
\end{tabular}

\section{Analisis Data Pelaksanaan Proses} Pembelajaran Berbasis Problem Based Learning (PBL)

Data pelaksanaan proses pembelajaran ini meliputi: a) kegiatan Pendahuluan, b) kegiatan inti mencakup kegiatan mengamati, menanya, mengumpulkan informasi, mengasosiasi dan mengkomunikasikan hasil, c) kegiatan penutup.

a. Data Kegiatan Pendahuluan Pembelajaran Berbasis Problem Based Learning (PBL)

Pada kegiatan awal diantaranya menyiapkan mahasiswa secara psikis dan fisik untuk mengikuti proses pembelajaran, mengajukan pertanyaan-pertanyaan tentang materi yang sudah dipelajari dan terkait dengan materi yang akan dipelajari, mengantarkan mahasiswa kepada suatu permasalahan atau tugas yang akan dilakukan untuk mempelajari suatu materi dan menjelaskan tujuan pembelajaran atau Kemampuan Akhir Yang Direncanakan yang akan dicapai; dan menyampaikan garis besar cakupan materi dan penjelasan tentang kegiatan yang akan dilakukan peserta didik untuk menyelesaikan permasalahan atau tugas.

Data kegiatan pendahuluan pada observasi pertama menunjukkan bahwa guru mengawali pembelajaran dengan melihat kesiapan mahasiswa dalam mengikuti pelajaran, dengan mengawalinya menggunakan salam, dan dilanjutkan bertanya tentang tugas yang diberikan pada pertemuan sebelumnya.

Data kegiatan pendahuluan pada observasi ketiga menunjukkan bahwa guru mengawali pembelajaran dengan salam dan bertanya sampai mana materi dan adakah tugas pada pertemuan sebelumnya. Dari analisis kegiatan awal dalam pembelajaran berbasis Problem Based Learning (PBL) pada observasi pertama dan ketiga tersebut dapat diambil kesimpulan sebagai berikut.

Tabel 6. Kesimpulan Analisis kegiatan pendahuluan dan hasil triangulasi waktu.

\begin{tabular}{|l|lr|}
\hline \multicolumn{3}{|c|}{ Kegiatan Pendahuluan } \\
\hline \multicolumn{2}{|c|}{ Observasi pertama } & \multicolumn{2}{c|}{ Observasi ketiga } \\
\hline Dosen membuka dengan & Dosen membuka \\
salam dan bertanya terkait & dengan salam dan \\
tugas yang diberikan & bertnya rakah \\
sebelumnya. tujuannya & kesulitan terkait \\
mahasiswa & bisa & tugas sebelumnya \\
mengaplikasikan kegiatan & dan raprat \\
PBL. & mahasiswa yang \\
\hline
\end{tabular}

Hasil triangulasi waktu data kegiatan pendahuluan dalam PBL:

Dosen membuka dengan salam dan bertanya terkait tugas dipertemuan sebelumnya, dan ada mahasiswa yang sudah aktif bertanya.

b. Data Kegiatan Inti Pembelajaran Berbasis Problem Based Learning (PBL)

Data dalam bentuk transkrip pada observasi pertama dan ketiga direduksi dengan cara mengkategorikan kegiatan pelaksanaan pembelajaran pada kegiatan inti ke dalam lima kategori. Kategori tersebut diantaranya adalah kegiatan mengamati, menanya, mengumpulkan informasi, mengasosiasi, dan menmgkomunikasikan hasil. Masing-masing dijelaskan sebagai berikut.

1) Data kegiatan mengamati dalam pelaksanaan proses pembelajaran berbasis Problem Based Learning (PBL)

Kategori ini berisi kumpulan aktivitas dosen dalam kegiatan mengamati pada saat pelaksanaan PBL dengan. Pada kategori ini data kegiatan mengamati pada observasi pertama dan ketiga dijelaskan sebagai berikut. 
Data kegiatan mengamati pada observasi pertama menunjukkan bahwa kegiatan mengamati dalam proses pembelajaran berbasis Problem Based Learning (PBL) yaitu dosen memberi kesempatan mahasiswa untuk melakukan pengamatan melalui kegiatan: melihat, menyimak, mendengar dan membaca.

Data kegiatan mengamati pada observasi ketiga menunjukkan bahwa Dosen memberikan permasalahan kemudian Dosen menerangkan atau memberikan sedikit batu loncatan tentang materi yang akan dipelajari dengan cara membahas tugas yang diberikan pada pertemuan sebelumnya, kemudian mengaitkanan dengan materi yang akan dipelajari. Cara tersebut dipilh karena tugas yang diberikan masih ada kaitanya dengan materi yang akan dipelajari agar mahasiswa dalam kegiatan mengamati juga lebuh mudah.

Berdasarkan analisis kegiatan mengamati dalam pembelajaran berbasis Problem Based Learning (PBL) pada observasi pertama dan ketiga tersebut dapat diambil kesimpulan sebagai berikut:

Tabel 7. Kesimpulan Analisis kegiatan mengamati dalam pelaksanaan pembelajaran

\begin{tabular}{|c|c|}
\hline \multicolumn{2}{|c|}{ Kegiatan Mengamati } \\
\hline Observasi pertama & Observasi ketiga \\
\hline $\begin{array}{lr}\text { Dosen } & \text { memberikan } \\
\text { sedikit } & \text { penjelasan } \\
\text { setelah } & \text { permasalahan } \\
\text { diberikan } & \text { kepada } \\
\text { mahasiswa, } & \text { supaya } \\
\text { lebih } & \text { mudah } \\
\text { mengamati. } & \text { Kemudian } \\
\text { mahasiswa } & \text { diminta } \\
\text { untuk membaca } & \text { sumber } \\
\text { belajar. }\end{array}$ & $\begin{array}{lr} & \text { Dosen memberikan } \\
\text { batu loncatan berupa } & \\
\text { Tugas yang diberikan } \\
\text { pada pertemuan } \\
\text { sebelumnya. Tugas } \\
\text { digunakan untuk } \\
\text { membantu mahasiswa } \\
\text { ketika diberikan } \\
\text { permasalahan. }\end{array}$ \\
\hline $\begin{array}{l}\text { Hasil triangulasi waktu } \\
\text { dalam PBL: } \\
\text { Dosen memberikan se } \\
\text { setelah memberikan } \\
\text { meminta mahasiswa m } \\
\text { yang dimiliki. }\end{array}$ & $\begin{array}{l}\text { ata kegiatan mengamati } \\
\text { likit materi pengantar } \\
\text { permasalahan. Dosen } \\
\text { mbaca sumber belajar }\end{array}$ \\
\hline
\end{tabular}

2) Data kegiatan menanya dalam pemebelajaran berbasis Problem Based Learning (PBL)
Dalam ketegori ini diperoleh data dari hasil observasi pertama dan ketiga adalah sebagai berikt.

Data kegiatan menanya pada observasi pertama yaitu dosen membuka kesempatan secara luas kepada mahasiswa untuk bertanya mengenai apa yang sudah dilihat, disimak, dibaca atau dilihat. Mahasiswa mengajukan pertanyaan. Pertanyaan tentang yang hasil pengamatan objek yang konkrit sampai kepada yang abstrak berkenaan dengan fakta, konsep, prosedur, atau pun hal lain yang lebih abstrak.

Pembentukan kelompok juga diperlukan, untuk lebih mengembangkan sosial mahasiswa dan diharapkan mahasiswa juga lebih bisa mengembangkan rasa ingin tahu dan bertanya. Kegiatan tersebut sudah dilaksanakan secara maksimal didalam pembelajaran berbasis PBL.b.Data kegiatan menanya pada observasi ketiga yaitu mahasiswa dilatih mengajukan pertanyaan, namun pada kenyataan siswa masih memerlukan bantuan guru untuk mengajukan pertanyaan dan ada mahasiswa yang sudah mampu mengajukan pertanyaan secara mandiri. Dari analisis kegiatan menanya dalam pembelajaran berbasis Problem Based Learning (PBL) pada observasi pertama dan ketiga tersebut dapat diambil kesimpulan sebagai

Tabel 8. Kesimpulan Analisis kegiatan menanya dalam pelaksanaan pembelajaran

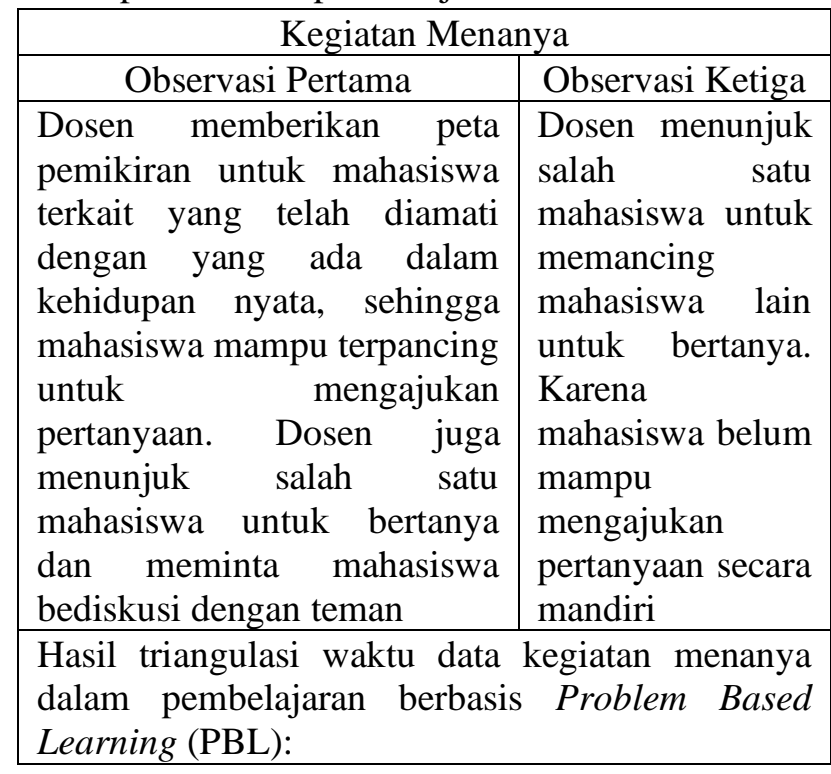


Dosen membantu mahasiswa dalam mengajukan pertanyaan, karena tidak semua mahasiswa bisa mengajukan pertanyaan secara mandiri. Hal tersebut dilakukan dengan menunjuk salah satu siswa untuk mengajukan pertanyaan atau sekedar menjawab pertanyaan dari dosen.

3) Data kegiatan mengumpulkan informasi dalam pemebelajaran berbasis Problem Based Learning (PBL)

Data pada kategori ini diperoleh dari observasi pertama dan ketiga yaitu sebagai berikut.

Data kegiatan mengumpulkan informasi pada observasi pertama yaitu mahasiswa menggali dan mengumpulkan informasi dari berbagai sumber melalui berbagai cara. Untuk itu mahasiswa dapat membaca buku yang lebih banyak, memperhatikan fenomena atau objek yang lebih teliti atau bahkan melakukan eksperimen. Pada lampiran observasi pertama pada kegiatan mengumpulkan informasi, mahasiswa kebanyakan hanya memiliki sumber belajar berupa internet.

Data kegiatan mengumpulkan informasi pada observasi ketiga yaitu mahasiswa hanya membaca buku ajar yang ada dan membacca pengetahuan dari internet.

Dari analisis kegiatan mengumpulkan informasi dalam pembelajaran berbasis Problem Based Learning (PBL) pada observasi pertama dan ketiga tersebut dapat diambil kesimpulan sebagai berikut.

Tabel 9. Kesimpulan Analisis kegiatan mengumpulkan informasi dalam pelaksanaan pembelajaran

\begin{tabular}{|l|lr|}
\hline \multicolumn{2}{|c|}{ Kegiatan Mengumpulkan Informasi } \\
\hline \multicolumn{2}{|c|}{ Observasi pertama } & \multicolumn{2}{|c|}{ Observasi ketiga } \\
\hline Dalam yang \\
mengumpulakn informasi & Usaha & dilakukan \\
mahasiswa membaca & mahasiswa ketika \\
sumber belajar yaitu buku & mengumpulkan \\
ajar Fisika Dasar II dan & informasi salah \\
referensi internet. & satunyardengan \\
& membaca buku dan \\
& referensi internet. \\
\hline
\end{tabular}

Hasil triangulasi waktu data kegiatan mengumpulkan informasi dalam pembelajaran berbasis masalah dengan pendekatan ilmiah di kelas X:

Pada kegiatan mengumpulkan informasi siswa hanya membaca buku ajar Fisika Dasar II dan referensi internet.

4) Data kegiatan mengasosiasi dalam pemebelajaran berbasis Problem Based Learning (PBL)

Dari kegiatan mengumpulkan informasi terkumpul sejumlah informasi. Informasi tesebut menjadi dasar bagi kegiatan berikutnya yaitu mengolah informasi untuk menemukan pola. Dalam ketegori ini diperoleh data dari hasil observasi pertama dan ketiga yaitu sebagai berikut.

Data kegiatan mengasosiasi pada observasi pertama yaitu guru menjadi fasilitator dengan cara menjawab pertanyaan dan membantu mahasiswa mengolah informasi-informasi yang diperoleh.

Data kegiatan mengasosiasi pada observasi ketiga yaitu mahasiswa bersama guru mengolah informasi yang telah diperoleh. Guru bertindak sebagai fasilitator, ketika mahasiswa menemukan informasi atau masih ragu dengan informasi atau dugaan yang mereka peroleh. Guru menjawab dan mengarahkan mahasiswa untuk mendekati pola atas penyelesaian permaslahan yang diberikan.

Dari analisis kegiatan mengasosiasi dalam pembelajaran berbasis Problem Based Learning (PBL) pada observasi pertama dan ketiga tersebut dapat diambil kesimpulan sebagai berikut.

Tabel 10. Kesimpulan Analisis kegiatan mengasosiasi dalam pelaksanaan pembelajaran

\begin{tabular}{|c|c|}
\hline \multicolumn{2}{|c|}{ Kegiatan Mengasosiasi } \\
\hline Observasi pertama & Observasi ketiga \\
\hline \begin{tabular}{lr}
\multicolumn{2}{l}{ Dalam kegiatan mengasosia, } \\
mengolah informasi ada \\
sedikit mahasiswa masih \\
kesulitan. Ketika mahsiswa \\
masih ragu dosen \\
mengarahkan & dengan \\
menjawab rran pertanyaan \\
mahasiswa & \multicolumn{2}{c}{ sampai } \\
mahasiswa mendekati pola
\end{tabular} & $\begin{array}{l}\text { Dosen sebagai } \\
\text { fasilitator yaitu } \\
\text { dengan menjawab } \\
\text { dan mengarahkan } \\
\text { mahasiswa supaya } \\
\text { mampu mengolah } \\
\text { informasi. }\end{array}$ \\
\hline
\end{tabular}




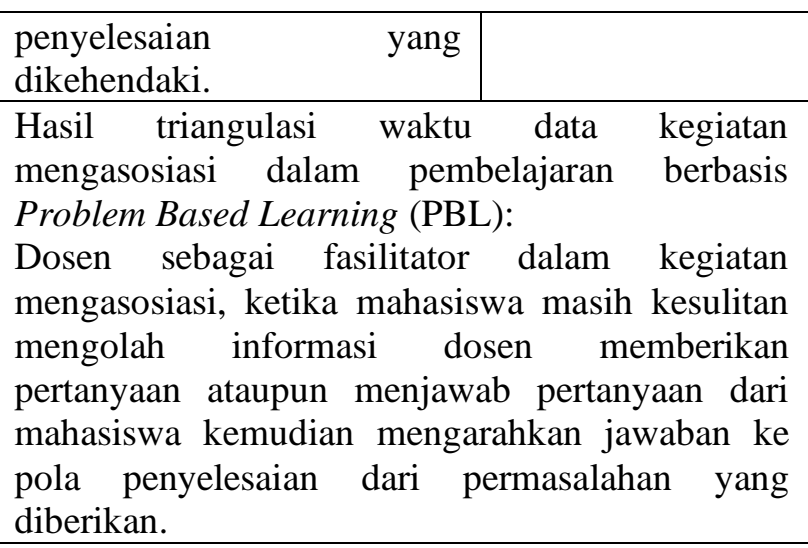

5) Data kegiatan mengkomunikasikan dalam pembelajaran berbasis Problem Based Learning (PBL)

Kegiatan mengkomunikasikan yaitu menuliskan atau menceritakan apa yang ditemukan dalam kegiatan-kegiatan sebelumnya. Data dalam ketegori ini diperoleh dari hasil observasi pertama dan ketiga yaitu sebagai berikut.

Data kegiatan mengkomunikasikan pada observasi pertama yaitu hasil mahasiswa yang sudah menemukan jawaban menampilkan jawaban yang ditemukan di depan kelas dan menyampaikannya kepada teman-teman satu kelas.

Data kegiatan mengkomunikasikan pada observasi ketiga diperoleh data yaitu dalam kegiatan mengkomunkasikan hasil, mahasiswa masih belum mempunyai keberanian pada kegiatan meyampaikan hasil pekerjaannya di depan kelas.

Dari analisis kegiatan mengkomunikasikan dalam pembelajaran berbasis Problem Based Learning (PBL) pada observasi pertama dan ketiga tersebut dapat diambil kesimpulan sebagai berikut.

Tabel 11. Kesimpulan Analisis kegiatan mengkomunikasikan dalam pelaksanaan pembelajaran

\begin{tabular}{|c|c|}
\hline \multicolumn{2}{|c|}{ Kegiatan mengkomunikasikan } \\
\hline Observasi pertama & Observasi ketiga \\
\hline $\begin{array}{l}\text { Mahasiswa } \\
\text { mempresentasikan hasil } \\
\text { yang diperoleh dan }\end{array}$ & $\begin{array}{l}\text { Mahasiswa } \\
\text { mempresentasikan } \\
\text { hasil pekerjaan dan }\end{array}$ \\
\hline
\end{tabular}

\begin{tabular}{|c|c|}
\hline $\begin{array}{l}\text { menjelaskan di depan } \\
\text { kelas. mahasiswa yang } \\
\text { lain memberikan } \\
\text { tanggapan dari apa yang } \\
\text { dijelaskan. }\end{array}$ & $\begin{array}{l}\text { menjelaskan hasil } \\
\text { yang diperoleh tetapi } \\
\text { guru harus menunjuk } \\
\text { salah satu mahasiswa. }\end{array}$ \\
\hline $\begin{array}{l}\text { Hasil triangulasi } \\
\text { mengkomunikasikan } \\
\text { berbasis Problem Based } L \\
\text { Keberanian mahasiswa } \\
\text { karena terkadang dosen } \\
\text { satu mahasiswa untuk } \\
\text { pekerjaannya. Untuk res } \\
\text { yang menjelaskan didepan }\end{array}$ & $\begin{array}{l}\text { tu data kegiatan } \\
\text { lam pembelajaran } \\
\text { arning (PBL) } \\
\text { asih belum maksimal } \\
\text { arus memanggil salah } \\
\text { mpresentasikan hasil } \\
\text { on ketika ada teman } \\
\text { kelas mahasiswa yang } \\
\text { it dengan menanggapi }\end{array}$ \\
\hline
\end{tabular}

c. Data Kegiatan Penutup Pembelajaran Berbasis Problem Based Learning (PBL)

Dalam kegiatan penutup, Dosen bersamasama dengan mahasiswa dan/atau sendiri membuat rangkuman/simpulan pelajaran, melakukan penilaian dan/atau refleksi terhadap kegiatan yang sudah dilaksanakan secara konsisten dan terprogram, memberikan umpan balik terhadap proses dan hasil pembelajaran, merencanakan kegiatan tindak lanjut dalam bentuk pembelajaran remedi, program pengayaan, layanan konseling dan/atau memberikan tugas baik tugas individual maupun kelompok sesuai dengan hasil belajar mahasiswa, dan menyampaikan rencana pembelajaran pada pertemuan berikutnya.

Kegiatan penutup pada observasi pertama dan ketiga dalam proses pembelajaran berbasis Problem Based Learning (PBL) ini dosen hanya melakukan kegiatan menyimpulkan bersamasama dengan mahasiswa tentang apa yang telah dipelajari dan memberikan tugas dan menutup dengan salam.

B. Pembahasan

1. Perencanaan Pembelajaran Berbasis Problem Based Learning (PBL)

Hasil penelitian berkaitan dengan proses Pembelajaran Berbasis Problem Based Learning (PBL), kesiapan dosen dan mahasiswa sangat diperlukan sebelum dimulainya pembelajaran. Sebelum pembelajaran dimulai Dosen menyiapkan media dan sumber belajar yang 
diperlukan untuk membantu selama proses pembelajaran. Untuk mahasiswa juga mempersiapkan tugas dan sumber belajar yang digunakan selama proses pembelajaran.

Rencana Pelaksanaan Pembelajaran (RPP) yang digunakan dosen dalam proses pembelajaran berbasis Problem Based Learning (PBL) yakni dalam kegiatan inti memuat kegiatan mengamati, menanya, mencoba, mengkomunikasikan. Dalam kegiatan inti tersebut pada setiap kegiatan/tahap terdapat indikator-indikator yang dosen dan mahasiswa lakukan.

Hasil penelitian berkaitan dengan kegiatan dalam proses Pemebelajaran Berbasis Problem Based Learning (PBL) menunjukkan bahwa dosen sudah berusaha melaksanakan semua tahapan atau kegiatan yang ada dalam model pembelajaran tersebut.

Berdasarkan analisis data hasil dokumentasi dan wawancara dengan dosen Pengampu Mata Kuliah Fisika Dasar II terdapat kesamaan bahwa dosen menyusun RPP sendiri dan mengembangkannya. Karena RPP dibuat mengacu pada silabus yang sudah disepakati oleh program studi. Namun dosen tetap dituntut untuk lebih kreatif dan inovatif, tujuannya supaya pembelajaran berlangsung secara interaktif, inspiratif, menyenangkan, menantang, memotivasi mahasiswa untuk berpartisipasi aktif, serta memberikan ruang yang cukup bagi prakarsa, kreativitas, dan kemandirian sesuai dengan bakat, minat, dan mamampu memiliki kemampuan berpikir kritis.

2. Pelaksanaan Pembelajaran Berbasis Problem Based Learning (PBL)

Tahap kedua dalam pembelajaran menurut standar proses yaitu pelaksanaan pembelajaran yang meliputi kegiatan awal, kegiatan inti, dan kegiatan penutup.

Kegiatan awal dosen membuka dengan salam dan bertanya terkait tugas dipertemuan sebelumnya. Pada kegiatan inti pembelajaran berbasis Problem Based Learning (PBL) dikategorikan menjadi lima pengalaman belajar yaitu: a) mengamati, b) menanya, c) mengumpulkan informasi, d) mengasosiasi, dan e) mengkomunkasikan.

a. Kegiatan Mengamati

Dimulai dari kegiatan orientasi pada masalah dan mengamati, dosen memberikan sebuah permasalahan yang kemudian mahasiswa diminta mencari pemecahannya dan mahasiswa juga diminta membaca sumber belajar yang digunakan dalam pemebalajaran. Dosen juga memberikan sedikit materi pengantar setelah memberikan permasalahan.

b. Kegiatan Menanya

Dalam kegiatan mengorganisasikan dan menanya, pada kegiatan ini pembentukan kelompok tidak begitu maksimal karena terbatasnya waktu, untuk memudahkan dalam pembuatan kelompok dosen meminta mahasiswa berdiskusi dengan teman.

Dosen membantu mahasiswa dalam mengajukan pertanyaan, karena mahasiswa belum bisa mengajukan pertanyaan secara mandiri. Hal tersebut dilakukan dengan manunjuk salah satu mahasiswa untuk mengajukan pertanyaan atau sekedar menjawab pertanyaan dari Dosen.

Dalam kegiatan inti mahasiswa sudah aktif. Namun terdapat beberapa mahasiswa yang kurang aktif karena kurangnya motivasi dan keberanian bertanya atau mengemukakan gagasan atau pendapat. Usaha yang dilakukan dosen yakni memberikan motivasi dan kemudian dosen menunjuk salah satu mahasiswa untuk bertanya atau sekedar mengemukakan gagasan dan pendapatnya, pancingan seperti itu dapat membuat mahasiswa yang lain akhirnya berani dan mampu mengeluarkan pendapat yang mereka tentang pemecahan masalah yang diberikan. Dengan itu pula komunikasi antar dosen dengan mahasiswa maupun mahasiswa dengan mahasiswa dapat berjalan lebih baik sehingga dapat pula 
menciptakan suasana kelas yang mengundang rasa ingin tahu.

b. Kegiatan Mengumpulkan informasi

Pada tahap berikutnya yakni membimbing penyelidikan dan mengumpulkan informasi serta menganalisis. Dalam tahap ini mahasiswa melakukan perocbaan di luar kelas maupun di laboratorium IPA.

\section{c. Kegiatan Mengasosiasi}

Tahap berikutnya yakni mengembangkan hasil karya dan mengasosiasi, pada kegiatan tersebut mahasiswa cukup aktif ketika memang mahasiswa sudah mulai mengetahui perkiraan pemecahan masalah yang diberikan. Namun, ketika materi dirasa sulit dosen memberikan bantuan agar mahasiswa mampu mengolah informasi-informasi yang telah ditemukan. Dosen sebagai fasilitator dalam kegiatan mengasosiasi, ketika mahasiswa masih kesulitan mengolah informasi dosen memberikan pertanyaan ataupun menjawab pertanyaan dari mahasiswa kemudian mengarahkan jawaban ke pola penyelesaian dari permaslahan yang diberikan.

d. Kegiatan Mengkomunikasikan

Tahap mengkomunikasikan, dosen harus menunjuk salah satu untuk menunjukan pemecahan dari permasalahan yang diberikan dan memintanya untuk menjelaskan alasannya. Dengan seperti itu mahasiswa yang lain menjadi lebih berani bertanya dan menyampaikan hasil pemngamatan dan analisis mereka terhadap permasalahan yang diberikan. Secara tidak langsung sikap dalam belajar telah ditanamkan dosen dalam Pembelajaran Berbasis Problem Based Learning (PBL), hal tersebut juga menjadi salah satu alasan mengapa Pembelajaran Berbasis Problem Based Learning (PBL) dipilih yakni karena dapat mengembangkan sikap belajar yag baik.

Sejalan dengan Rakhshanda Tayyeb (2013) menunjukkan bahwa Problem Based Learning bila digunakan sebagai alat pembelajaran tidak secara signifikan mendorong berpikir kritis dan pemecahan masalah keterampilan, sedangkan itu tidak lumayan mempengaruhi akuisisi pengetahuan konten. Problem Based Learning merupakan alat pembelajaran yang efektif untuk mendorong pemikiran kritis dan keterampilan pemecahan masalah. Sejalan dengan penelitian Sharifah Norul Akmar bt Syed Zamri, Lee Siew Eng (2005) menyatakan Hasil penilaian menunjukkan bahwa metode Problem Based Learning memiliki dampak positif secara keseluruhan pada sikap siswa.

Kegiatan penutup dalam pembelajaran baik dalam observasi pertama dan ketiga pada proses pembelajaran berbasis Problem Based Learning (PBL) ini dosen hanya melakukan kegiatan menyimpulkan bersama-sama dengan mahasiswa tentang apa yang telah dipelajari dan memberikan tugasdan menutup dengan salam.

3. Kemampuan Berpikir Kritis dalam Pembelajaran Berbasis Problem Based Learning (PBL)

Salah satu kemampuan yang harus dimiliki oleh dosen adalah bagaimana menerapkan suatu model pembelajaran yang dapat meningkatkan kemampuan berpikir kritis mahasiswa serta sesuai dengan tujuan atau kompetensi yang akan dicapai. Berdasarkan hasil analisis data diperoleh bahwa Problem Based Learning (PBL) yang sudah diterapkan dosen berhasil mengembangkan kemampuan berpikir kritis mahasiswa pada kategori cukup.

Proses pembelajaran berbasis Problem Based Learning (PBL) ini mampu mengembangkan kemampuan berpikir kritis mahasiswa pada mata kuliah Fisika Dasar II. Kemampuan tersebut meliputi elementary clarification, basic support, inference, dan advanced clarification dalam kategori cukup.

Pada aspek Elementary clarification bahwa mahasiswa mampu memberikan penjelasan sederhana. Hal ini dibuktikan bahwa ketika melakukan praktikum fisika dasar II mahasiswa 
mampu merumuskan masalah. Selain itu mahasiswa mampu menganalisis argumen dari beberapa mahasiswa lainnya. Mahasiswa mampu bertanya dan menjawab suatu penjelasan atau tantangan yang diberikan oleh dosen maupun sesama mahasiswa lainnya.

Pada aspek basic support bahwa mahasiswa mampu membangun keterampilan dasar. Dalam menumpulkan informasi mahasiswa memiliki kemampuan memberikan alasan, mengobservasi kemudian mempertimbangkan hasil observasi.

Pada aspek inference bahwa mahasiswa mampu menyimpulkan. Hal ini dibuktikan bahwa mahasiswa mampu menyatakan tentang beberapa hal mengenai alasan atau kesimpulan. Bahkan ada beberapa mahsiswa yang mampu mencari bukti di luar bukti yang telah ada. Sebagian besar mahasiswa mampu mengusulkan kesimpulan yang sesuai dengan fakta- fakta yang telah diketahui (esensial).

\section{PENUTUP}

\section{Simpulan}

1. Perencanaan pembelajaran dianalis dari penyusunan RPP sudah baik sekali. Dosen sudah menyusun RPP sesuai dengan silabus yang kemudian dikembangkan sesuai dengan karakteristik mahasiswa prodi Pendidikan IPA STKIP Modern Ngawi. RPP sudah terlengkapi dengan PBL antara lain tujuan pembelajaran, mengembangkan kegiatan pembelajaran, penjabaran jenis penilaian, menentukan alokasi waktu, dan menentukan sumber belajar.

2. Proses pembelajaran sudah baik, hal ini ditunjukkan dengan a) sintaks pembelajaran PBL pada kegiatan mengamati, menanya, mengumpulkan informasi, mengasosiasi, dan mengkomunikasikan terlaksana dengan baik, b) Proses pembelajaran berbasis Problem Based Learning (PBL) ini mampu mengembangkan kemampuan berpikir kritis mahasiswa pada mata kuliah Fisika Dasar II. Kemampuan tersebut meliputi elementary clarification, basic support, inference, dan advanced clarification dalam kategori cukup.

\section{Saran}

Berdasarkan kesimpulan penelitian di atas, dapat disampaikan saran sebagai berikut: 1) Dosen harus menyusun perencanaan pembelajaran dengan baik agar proses pembelajaran bisa berjalan dengan maksimal dengan menerapka pembelajaran yang mampu meningkatkan kemampuan berpikir kritis mahasiswa salah satunya adalah Problem Based Learning (PBL); dan 2) Mahasiswa lebih meningkatkan kemampuan berpikir kritis sehingga mampu menyelesaikan masalah, menganalisa, dan mampu menyimpulkan sesuai dengan fakta-fakta.

\section{DAFTAR PUSTAKA}

Amir, M. T. 2010. Inovasi Pendidikan Melalui Problem Based Learning: Bagaimana Pendidik Memberdayakan Pembelajara di Era Pengetahuan. Jakarta: Kencana Prenada Media Group.

Ibrahim, M. 2008. Model Pengembangan Perangkat Pembelajaran Menurut Jerold E. Kemp \& Thiagarajan. Surabaya: FPMIPA Universitas Negeri Surabaya.

Lambertus. 2009. Pentingnya Melatih Keterampilan Berpikir Kritis Dalam Pembelajaran Matematika di SD. Forum Kependidikan. Volume: 28, Nomor: 2, hal. 136-142.

Nur, M. 2008. Model Pembelajaran Berdasarkan Masalah. Surabaya: Pusat Sains dan Matematika Sekolah Universitas Negeri Surabaya.

Sardiman. 2011. Interaksi dan Motivasi Belajar Mengajar. Jakarta: PT Raja Grafindo Persada.

Sharifah Norul Akmar bt Syed Zamri, Lee Siew En. 2005. Integrating Problem Based Learning (PBL) in Mathematics Method Course. Journal of Problem Based Learning, 3 (1). 
Sugiyono. 2008. Metode Penelitian Kuantitatif, Kualitatif, dan $R \& D$. Bandung: Alfabeta.

Tayyeb, Rakhshanda. 2013. "Effectiveness of Problem Based Learning as an Instructional Tool for Acquisition of Content Knowledge and Promotionof Critical Thinking Among Medical Students", Journal of College of Dokter dan Ahli Bedah Pakistan, 23(1): 42-46 